\title{
Feasibility studies of the influence of fuels of different composition, including coal-enrichment waste, on the reliability of the boiler operation
}

\author{
Elina Tyurina ${ }^{1,2,}{ }^{*}$, Maxim Izhganaytis ${ }^{2}$, Aleksandr Mednikov ${ }^{1}$, Pavel Elsukov $^{1}$, and Ekaterina Samarkina ${ }^{2}$ \\ ${ }^{1}$ ESI SB RAS, 130 Lermontov str., 664033 Irkutsk, Russia \\ ${ }^{2}$ Irkutsk National Research Technical University, 83 Lermontov str., 664074 Irkutsk, Russia
}

\begin{abstract}
The possibility of using waste from coal processing enterprises as an alternative fuel with the simultaneous binding of sulfur oxides in the boiler furnace is considered. A mathematical model of the boiler unit has been developed, with the use of which verification calculations of the boiler were carried out with the determination of the rates of abrasive wear of convective heat exchange surfaces and corrosive wear of the air heater.The dependences of the characteristic parameters of the boiler unit operation on the fuel composition are revealed.Technological and economic assessments of the use of fuels of various compositions, including wastes from coal processing plants and binding components (marble chips), to reduce sulfur oxide emissions are given.
\end{abstract}

\section{Introduction}

Comprehensive accounting of the consequences of changes in the composition of the combusted fuel is a rather difficult task that requires an assessment of the fuel and economic efficiency of TPPs, reliability and the rate of depletion of the resources of various elements of the main and auxiliary equipment.

In the presented work, a technical and economic assessment of the use of waste from coal processing enterprises (CEW) as an alternative fuel with the simultaneous binding of sulfur oxides in the boiler furnace is given. For this purpose, a mathematical model of a steam boiler was developed, which makes it possible to describe the processes occurring in it with sufficient accuracy.

\section{Mathematical modeling of a steam boiler on solid fuels of various compositions, including WS}

A boiler unit of standard size BKZ-75-39FB was chosen as the object of modeling, designed for flare combustion of coal dust (bituminous and brown coal) with solid ash removal. The nominal capacity of the boiler unit is $75 \mathrm{t} /$ $\mathrm{h}$, the operating pressure and temperature of the superheated steam are $3.8 \mathrm{MPa}$ and $440^{\circ} \mathrm{C}$, respectively.

On the basis of a boiler unit of this standard size, installed at one of the thermal power plants of Irkutskenergo, experimental combustion of the CEW was carried out. Based on the results obtained in the course of experimental combustion, it was concluded that it is possible to use CEW as a fuel additive to the main coal, for which their preliminary granulation is required (CEW have a high moisture content, which can lead to clogging of the path at the stage of fuel supply to the mills for grinding). At the same time, it was decided to investigate the possibility of reducing emissions of sulfur oxides with boiler flue gases, using the principle of chemisorption the addition of an active component to the granules, which will allow to bind some of the sulfur oxides in the boiler furnace.

The boiler unit model was developed using the computerbased program construction system (SMPP-PC) created at the ESI SB RAS, which automatically generates a mathematical model of the installation based on information about the mathematical models of individual elements, technological connections between them and calculation purposes.

Figure 1 shows a design diagram of a boiler unit, which includes the following elements: a combustion chamber (1), a combustion chamber (2), furnace screens (3), a drum (4), two stages of a convective superheater $(5,6)$, a desuperheater (7), serving to regulate the temperature of superheated steam during operation, two stages of a water economizer $(8,10)$, two stages of an air heater $(9,11)$, a draft fan (12) and a smoke exhauster (15), a scrubber for wet cleaning of flue gases (13), pump of water supplied to the scrubber for cleaning flue gases (14). In addition to these elements, the circuit uses a splitter (16) and a mixer (17) installed on the feed water line and providing cooling water supply to the desuperheater.

* Corresponding author: tyurina@isem.irk.ru 
Material (gas-air and steam-water) and energy (heat) flows are taken into account by the connections between the corresponding elements of the scheme.

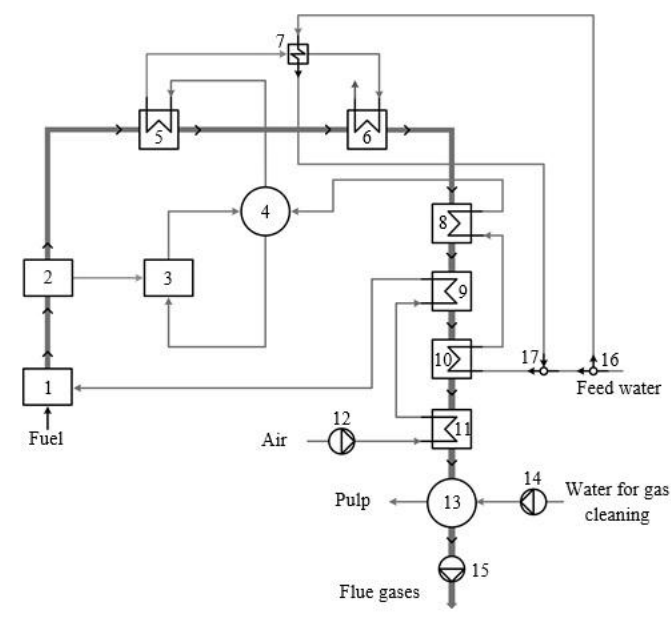

Fig. 1. Design diagram of the BKZ-75-39FB boiler

The developed mathematical model is identified in accordance with the experimental data obtained as a result of the experimental combustion of CEW and makes it possible to determine the characteristics and parameters of the boiler when operating on solid fuel of various compositions and various loads. This is required to assess the technological and environmental consequences of using fuels of various compositions, including CEW, and to organize measures to reduce sulfur oxide emissions.

\section{Binding of sulfur oxides and assessment of low-temperature corrosion of boiler heating surfaces}

As a component actively interacting with sulfur oxides, the waste of marble production (marble chips), containing significant amounts of $\mathrm{CaO}$ and $\mathrm{MgO}$ oxides, is considered.

The main binding chemical reactions are:

$$
\begin{aligned}
& \mathrm{CaO}+\mathrm{SO}_{2}+1 / 2 \mathrm{O}_{2}=\mathrm{CaSO}_{4}, \\
& \mathrm{MgO}+\mathrm{SO}_{2}+1 / 2 \mathrm{O}_{2}=\mathrm{MgSO}_{4} .
\end{aligned}
$$

The use of this method of binding sulfur oxides in the combustion chamber has an important feature - the introduction of marble production waste into the flue gases can change the chemical composition of the ash and, as a result, reduce the temperature of the onset of ash deformation, which can lead to increased slagging of heating surfaces.

The calculation of the binding of sulfur oxides is carried out on the basis of methodological instructions and experimental data $[1,3,5]$.

The fraction of sulfur oxides $\left(\eta_{S O x}\right)$ bound by the fuel fly ash is taken in accordance with Table 1, depending on the molar ratio:

$$
\mathrm{Ca}^{\mathrm{eq}} / \mathrm{S}=5,71 \cdot 10^{-3} \cdot \mathrm{A}^{\mathrm{r}} / \mathrm{S}^{\mathrm{r}} \cdot(\mathrm{CaO}+1,39 \mathrm{MgO}),
$$

where $\mathrm{CaO}, \mathrm{MgO}$ is the content of calcium and magnesium oxides in the ash of the fuel containing CEW and marble chips, wt \%.

Table 1. Efficiency of binding of Sulfur oxides depending on the molar ratio of components.

\begin{tabular}{|c|c|c|c|c|c|c|}
\hline $\mathrm{Ca}^{\mathrm{eq}} / \mathrm{S}$ & 0,8 & 1,0 & 1,5 & 2,0 & 2,5 & 3,0 \\
\hline$\eta_{\mathrm{Sox}}$ & 0,10 & 0,18 & 0,36 & 0,55 & 0,69 & 0,80 \\
\hline
\end{tabular}

To calculate the rate of corrosive wear of the metal of the pipes of the air heater of the first stage of the boiler unit, the tabular data set forth in [4] are used. On the basis of these data, approximation dependences of the rate of lowtemperature corrosion of metal on the average temperature of the pipe wall and the reduced 2 ulphur content of the combusted fuel were constructed (Fig. 2).

\section{Abrasive wear of convective heat transfer surfaces of the boiler unit}

Of all the negative factors caused by a change in the composition of the fuel, in particular by an increase in the ash content of coal, the most significant is the ash wear of the convective heating surfaces of boilers, which causes them to be taken into emergency repair with a corresponding underproduction of energy.

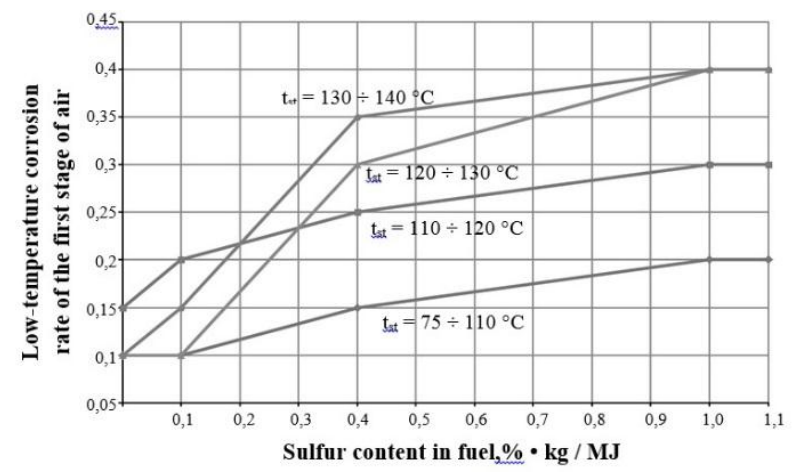

Fig. 2. Dependence of the low-temperature corrosion rate of the $1^{\text {st }}$ stage of air heater on the reduced 2 ulphur content in the initial fuel and the average tube wall temperature

Ash wear of convective heating surfaces of steam generators, the pipe wall temperature of which does not exceed $350^{\circ} \mathrm{C}$, can be considered as a purely mechanical process. In this case, the properties of the wear material do not change, and the wear coefficient characterizes the properties of the abrasive. Therefore, in relation to ash wear of convective heating surfaces, the wear coefficient can be taken equal to the ash abrasiveness coefficient, determined with respect to the material of boiler pipes.

Approximate values of the ash abrasiveness coefficient are calculated depending on the content in the ash $\left(\mathrm{SiO}_{2}+\mathrm{Al}_{2} \mathrm{O}_{3}\right), \%$ by the formula: 


$$
\mathrm{a}_{20}=0,045 \cdot\left(\mathrm{SiO}_{2}+\mathrm{Al}_{2} \mathrm{O}_{3}-44\right) \cdot 10^{-12}, \mathrm{~m}^{2} / \mathrm{N}
$$

The abrasiveness of ash particles primarily depends on the $\mathrm{SiO}_{2}$ content in the ash and increases markedly when $\mathrm{SiO}_{2}>60 \%$.

Knowing the abrasiveness coefficient and operating conditions of boiler pipes (gas velocity and temperature, ash concentration, uneven velocity and concentration fields), it is possible to calculate the value of ash wear of steam generator pipes and estimate the service life of convective heating surfaces when operating on fuel of various compositions.

The calculation of the rates of abrasive wear of the poisonous economizer and the air heater is carried out in accordance with [6].

The values of velocities, volumes and temperatures of gases, ash concentration, etc., required for studies of abrasive wear of convective heating surfaces were determined as a result of the verification calculation of the boiler.

\section{Determination of costs associated with the replacement of project fuel with alternative fuel, including CEW}

Changes in the qualitative characteristics of solid fuel have an impact not only on the operation of the main and auxiliary boiler equipment, but also on the performance indicators of the fuel supply and ash removal systems. The consequences of a change in the composition of the burned fuel on the operation of equipment must be taken into account throughout the entire technological chain of fuel use: from unloading and storing coal to emissions of harmful substances into the atmosphere, transportation and storage of ash and slag waste, etc.

To take into account these consequences, the work uses the methodology for determining costs when using solid fuels of various compositions at TPPs, developed in the ESI SB RAS [7]. This methodology allows one to determine the costs associated with replacing the design fuel with an alternative one, and to assess the economic feasibility of using an alternative fuel.

Part of the total annual costs associated with changes in the properties of fuel and its price can be presented as a sum

$$
\mathrm{TC}=\mathrm{C}^{1}+\ldots+\mathrm{C}^{11}
$$

and includes: costs for the purchase and transportation of fuel; costs of operation and repair of the unloading, storage and fuel supply system; costs of repairing the main and auxiliary boiler equipment; costs of operation and repair of ash collection systems; costs for operation and repair of CEW ash removal systems; costs of storing ash and slag; payment for ash and sulfur oxides emissions. The technique has been improved and allows one to take into account the costs associated with a change in the rate of low-temperature corrosion of the 1st stage air heater through a change in its service life, which is reflected in the costs of repairing the main boiler equipment.

\section{Calculation results based on the mathematical model of the boiler}

The initial fuel in the calculations is coal from the Cheremkhovskoye deposit $\left(\mathrm{W}^{\mathrm{r}}-15.0 \%, \mathrm{~A}^{\mathrm{r}}-29.8 \%, \mathrm{~S}^{\mathrm{r}}\right.$ $-2.0 \%, \mathrm{C}^{\mathrm{r}}-42.5 \%, \mathrm{H}^{\mathrm{r}}-3.1 \%, \mathrm{~N}^{\mathrm{r}}-0.6 \%, \mathrm{O}^{\mathrm{r}}-8.1 \%$, $\mathrm{LHV}-16410.0 \mathrm{~kJ} / \mathrm{kg}$ ). An alternative fuel is a mixture of Cheremkhovsky coal with granular CEW $\left(\mathrm{W}^{\mathrm{r}}-26.6 \%\right.$, $\mathrm{A}^{\mathrm{r}}-28.1 \%, \mathrm{~S}^{\mathrm{r}}-0.55 \%, \mathrm{C}^{\mathrm{r}}-36.76 \%, \mathrm{H}^{\mathrm{r}}-2.68 \%, \mathrm{~N}^{\mathrm{r}}-$ $0.52 \%, \mathrm{O}^{\mathrm{r}}-7.0 \%$, LHV - $12537.1 \mathrm{~kJ} / \mathrm{kg}$ ) with the content of the last $30 \%, 50 \%$ and $70 \%$. A $50 \%$ bitumen emulsion is used as a binding component in granulation, at a cost of $6,000 \mathrm{rub} / \mathrm{ton}$. The calculation is made for two compositions of granules - without and with the addition of a component that binds sulfur oxides - marble chips $\left(\mathrm{CaO}-59.22 \%, \mathrm{SiO}_{2}-22.49 \%, \mathrm{MgO}-17.4 \%, \mathrm{Al}_{2} \mathrm{O}_{3}-\right.$ $0.487 \%, \mathrm{Fe}_{2} \mathrm{O}_{3}-0.115 \%$ and others), costing 2,100 rub/ton, including delivery. The cost of CEW is $196 \mathrm{rub} / \mathrm{t}$. The calculation also takes into account the cost of the granulator in the amount of 3 million rubles, the cost of granulating $\mathrm{CEW}$, changes in the rates of abrasive wear and low-temperature corrosion. The initial data for the calculation were taken according to the actual values provided by the CHP.

Based on the calculation results, the dependences are plotted, shown in Figures 3-6.

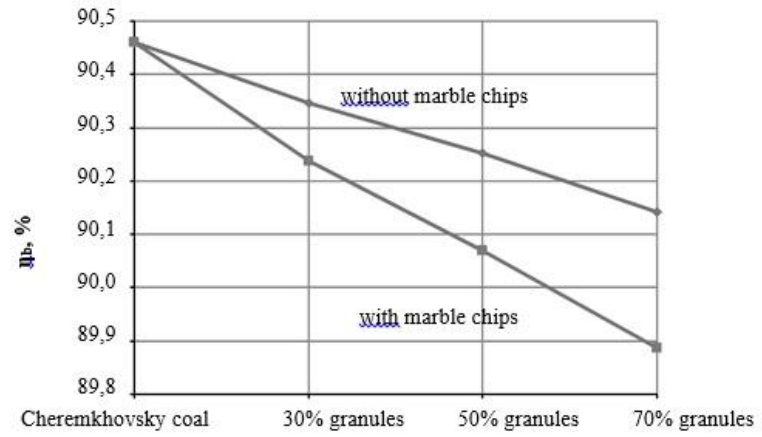

Fig. 3. Change in boiler gross efficiency $\left(\eta_{\mathrm{b}}\right)$ when burning fuel of different composition

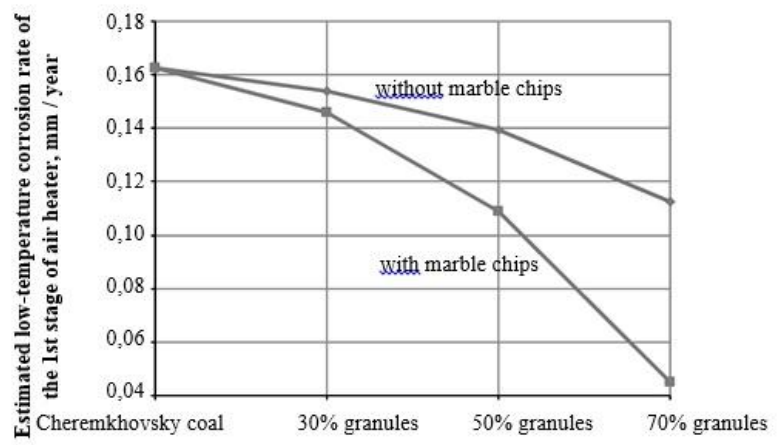

Fig. 4. Change in the rate of low-temperature corrosion of the1st stage of air heater 


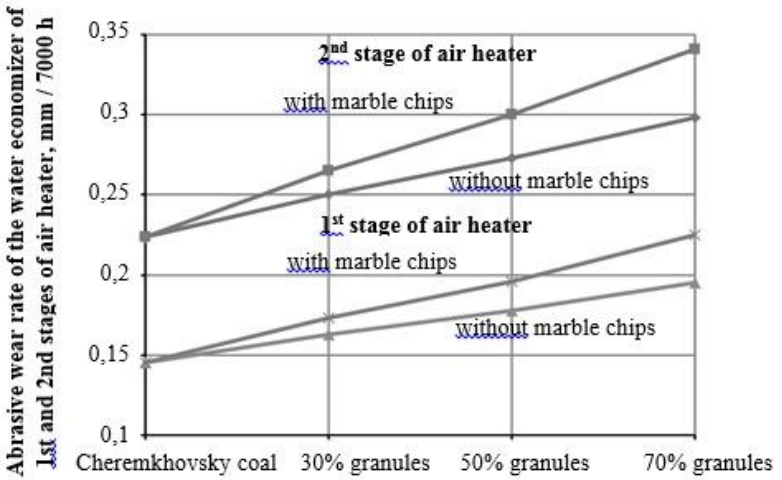

Fig. 5. Change in the rate of abrasive wear of 1 st and 2 nd stages of air heater

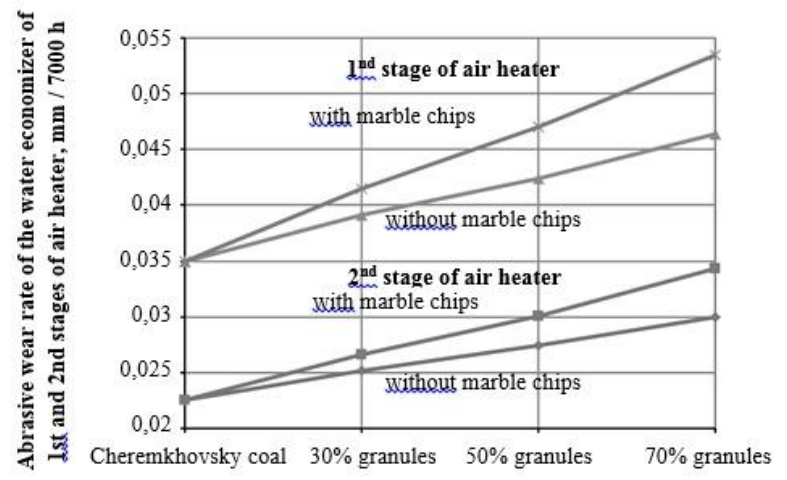

Fig. 6. Change in the rate of abrasive wear of 1st and 2nd stages of air heater

\section{Conclusion}

Tables 2, 3 show the total annual costs associated with replacing the original fuel (Cheremkhovsky coal) with an alternative one.

Based on the analysis of the calculation results, the following conclusions were made.

1. The cost of 1 ton of natural fuel is reduced when granular CEW is added. Nevertheless, the cost of 1 ton of standard fuel increases, since when CEW is added to the fuel composition, its calorific value decreases. When marble chips are added to the fuel, the cost of both natural and coal equivalent fuel increases. Together with an increase in the cost of producing granules, this leads to an increase in the total costs of purchasing, transporting, unloading, storing and supplying fuel.

2. A decrease in the quality of the fuel (the heat of combustion of the combusted mixture) leads to an increase in its consumption, which is necessary to maintain the steam capacity of the boiler, and, as a consequence, to an increase in the volume of emissions of solid particles with flue gases. Changing the parameters of the flue gas flow leads to an increase in the rate of abrasive wear of convective heat exchange surfaces. The corresponding components of the total costs are also increasing - the cost of repairing the water economizer, the cost of operating and repairing ash collection and ash removal systems, the cost of storing ash and slag, and payment for the emission of ash particles. The addition of marble chips to the fuel also leads to an increase in the costs of repairing the dust preparation system, which is due to an increase in the ash content of the combusted mixture.

3. A decrease in the sulfur content in the fuel when CEW is added to its composition and the binding of sulfur oxides by the active constituents of marble chips leads to a significant decrease in their concentration in the exhaust gases and, as a consequence, to a decrease in the dew point temperature and a decrease in the rate of low-temperature corrosion. The corresponding components of the total costs are also reduced - the cost of repairing the air heater (the rate of low-temperature corrosion significantly more affects the service life of the lower cubes of the air heater than the rate of abrasive wear) and the payment for sulfur oxide emissions.

Table 2. The value of the total costs and their components for various options for the composition of the fuel without marble chips.

\begin{tabular}{|l|c|c|c|c|}
\hline \multirow{2}{*}{ Fuel composition } & Coal & \multicolumn{3}{|c|}{$\begin{array}{c}\text { Coal mix with granular waste } \\
\text { from coal preparation } \\
\text { (coal/CEW) }\end{array}$} \\
\cline { 2 - 5 } & $\begin{array}{c}70 \% / \\
30 \%\end{array}$ & $\begin{array}{c}50 \% / \\
50 \%\end{array}$ & $\begin{array}{c}30 \% / \\
70 \%\end{array}$ \\
\hline $\begin{array}{l}\text { Cost of 1 ton of } \\
\text { fuel, including } \\
\text { delivery, rub. }\end{array}$ & 830 & 813,9 & 803,2 & 792,48 \\
\hline fuel equivalent & 1482,1 & 1538,7 & 1580,3 & 1625,4 \\
\hline $\begin{array}{l}\text { Costs for the } \\
\text { purchase, } \\
\text { transportation, } \\
\text { storage and } \\
\text { supply of fuel, } \\
\text { rub/tfe. }\end{array}$ & 2100,7 & 2261,3 & 2307,1 & 2356,3 \\
\hline $\begin{array}{l}\text { Expenses for the } \\
\text { repair of main } \\
\text { and auxiliary } \\
\text { equipment, } \\
\text { rub/tfe. }\end{array}$ & 23,34 & 23,7 & 23,76 & 23,55 \\
\hline $\begin{array}{l}\text { Costs for the } \\
\text { operation and } \\
\text { repair of ash } \\
\text { collection } \\
\text { systems, ash and } \\
\text { slag removal } \\
\text { systems and for } \\
\text { storage of ash and } \\
\text { slag, rub/tfe. }\end{array}$ & 79,91 & 86,68 & 92,02 & 98,35 \\
\hline $\begin{array}{l}\text { Fee for emissions } \\
\text { of ash particles, } \\
\text { rub/tfe. }\end{array}$ & 62,3 & 63,95 & 65,03 & 66,02 \\
\hline
\end{tabular}




\begin{tabular}{|l|c|c|c|c|}
$\begin{array}{l}\text { Fee for emissions } \\
\text { of sulfur oxides, } \\
\text { rub/tfe. }\end{array}$ & 19,56 & 6,44 & 5,18 & 3,59 \\
\hline $\begin{array}{l}\text { Total costs } \\
\text { excluding the cost } \\
\text { of fuel, rub/tfe. }\end{array}$ & 807,3 & 903,4 & 912,81 & 922,93 \\
\hline $\begin{array}{l}\text { Total costs, } \\
\text { taking into } \\
\text { account the cost } \\
\text { of fuel, rub/tfe. }\end{array}$ & 2285,8 & 2442,1 & 2493,1 & 2548,3 \\
\hline
\end{tabular}

Table 3. The value of the total costs and their components for various options for the composition of the fuel with marble chips.

\begin{tabular}{|c|c|c|c|c|}
\hline \multirow[t]{2}{*}{ Fuel composition } & \multirow[t]{2}{*}{ Coal } & \multicolumn{3}{|c|}{$\begin{array}{l}\text { Coal mix with granular waste } \\
\text { from coal preparation } \\
(\text { coal/CEW })\end{array}$} \\
\hline & & $\begin{array}{c}70 \% / \\
30 \%\end{array}$ & $\begin{array}{c}50 \% / \\
50 \%\end{array}$ & $\begin{array}{c}30 \% / \\
70 \%\end{array}$ \\
\hline \multirow{2}{*}{$\begin{array}{l}\text { Cost of } 1 \text { ton of } \\
\text { fuel, including } \\
\text { delivery, rub. } \\
\text { natural } \\
\text { fuel equivalent }\end{array}$} & 830 & 871,04 & 898,4 & 925,76 \\
\hline & 1482,1 & 1698,3 & 1865,9 & 2056,9 \\
\hline $\begin{array}{l}\text { Costs for the } \\
\text { purchase, } \\
\text { transportation, } \\
\text { storage and } \\
\text { supply of fuel, } \\
\text { rub/tfe. }\end{array}$ & 2100,7 & 2424,1 & 2598,7 & 2797,7 \\
\hline $\begin{array}{l}\text { Expenses for the } \\
\text { repair of main } \\
\text { and auxiliary } \\
\text { equipment, } \\
\text { rub/tfe. }\end{array}$ & 23,34 & 25,2 & 25,78 & 25,67 \\
\hline $\begin{array}{l}\text { Costs for the } \\
\text { operation and } \\
\text { repair of ash } \\
\text { collection } \\
\text { systems, ash and } \\
\text { slag removal } \\
\text { systems and for } \\
\text { storage of ash and } \\
\text { slag, rub/tfe. }\end{array}$ & 79,91 & 112,29 & 142,46 & 181,84 \\
\hline $\begin{array}{l}\text { Fee for emissions } \\
\text { of ash particles, } \\
\text { rubles/tfe. }\end{array}$ & 62,3 & 64,95 & 70,63 & 129,23 \\
\hline $\begin{array}{l}\text { Fee for emissions } \\
\text { of sulfur oxides, } \\
\text { rub/tfe. }\end{array}$ & 19,56 & 6,23 & 4,19 & 1,54 \\
\hline $\begin{array}{l}\text { Total costs } \\
\text { excluding the cost } \\
\text { of fuel, rub/tfe. }\end{array}$ & 807,3 & 934,51 & 975,9 & 1079,1 \\
\hline $\begin{array}{l}\text { Total costs, } \\
\text { taking into } \\
\text { account the cost } \\
\text { of fuel, rub / tfe. }\end{array}$ & 2285,8 & 2632,8 & 2841,8 & 3136 \\
\hline
\end{tabular}

4. A decrease in the concentration of sulfur oxides in the exhaust gases leads to a decrease in the dew point temperature. This makes it possible to reduce the temperature of the flue gases and thereby slightly compensate for the decrease in the thermal efficiency of the boiler unit $\left(\eta_{\mathrm{b}}\right)$, caused by the deterioration of the fuel quality. However, the presence of anhydrous gypsum in the combustion products, which is formed as a result of the binding of sulfur oxides by calcium oxide, can lead to the formation of hard-to-remove gypsum deposits in water scrubbers, which leads to the need not only to select the optimal composition of the combusted mixture, but also to observe the exact chemical balance of the ash collector.

5. The obtained results show the possibility of binding of sulfur oxides by fly ash of a combusted mixture of Cheremkhovsky coal and CEW without adding marble chips (binding of sulfur oxides with a ratio of coal to CEW of $50 / 50$ and $30 / 70$ is $7.35 \%$ and $20.23 \%$, respectively). The highest binding of sulfur oxides is shown by variants using a mixture of Cheremkhovsky coal and granules, including marble chips, in proportions 50/50 and 30/70 $26.89 \%$ and $66.63 \%$, respectively.

Despite the fact that the introduction of granular CEW and marble chips into the fuel leads to a decrease in the content of sulfur oxides in the flue gases, the calculation results show an increase in the total costs of operating and repairing technological units for using fuel. The reasons for this are the deterioration of the quality of the fuel and the increase in its consumption, as well as the high cost of the components introduced into the composition of the initial fuel.

Table 4 shows the boundary values of the costs of the added components (bitumen emulsion and marble chips), upon reaching which, without reducing the cost of coal, the use of the given mixture compositions becomes expedient.

The last row of the table also shows the cost of coal, at which, without changing the cost of the components introduced into the mixture, the use of the given compositions becomes equal to the use of the original coal.

Table 4. Conditions of equal efficiency of alternative fuel to the design one (in terms of total costs).

\begin{tabular}{|l|c|c|c|}
\hline \multirow{2}{*}{ Fuel composition } & \multicolumn{3}{|c|}{$\begin{array}{c}\text { Coal mix with granular waste } \\
\text { from coal preparation } \\
\text { (coal/CEW) }\end{array}$} \\
\cline { 2 - 4 } & \multicolumn{3}{|c|}{ Without marble chips } \\
\cline { 2 - 4 } & $\begin{array}{c}70 \% / \\
30 \%\end{array}$ & $\begin{array}{c}50 \% / \\
50 \%\end{array}$ & $\begin{array}{c}30 \% / \\
70 \%\end{array}$ \\
\hline $\begin{array}{l}\text { The cost of bitumen } \\
\text { emulsion, rub/t }\end{array}$ & 3240 & 3890 & 4170 \\
\hline $\begin{array}{l}\text { Cost of marble chips, } \\
\text { rub/t }\end{array}$ & - & - & - \\
\hline Coal cost, rub/t & 1168 & 1088 & 1054,5 \\
\hline & \multicolumn{3}{|c|}{ With marble chips } \\
\hline
\end{tabular}




\begin{tabular}{|l|c|c|c|}
\hline $\begin{array}{l}\text { The cost of bitumen } \\
\text { emulsion, rub/t }\end{array}$ & $\begin{array}{c}70 \% / \\
30 \%\end{array}$ & $\begin{array}{c}50 \% / \\
50 \%\end{array}$ & $\begin{array}{c}30 \% / \\
70 \%\end{array}$ \\
\hline $\begin{array}{l}\text { Cost of marble chips, } \\
\text { rub/t }\end{array}$ & 1660 & 2210 & 2130 \\
\hline Coal cost, rub/t & 500 & 500 & 500 \\
\hline & 1653 & 1574 & 1589 \\
\hline
\end{tabular}

The research was carried out under State Assignment 17.1.4 (No AAAA-A17-117030310433-6) of the Fundamental Research of Siberian Branch of the Russian Academy of Sciences.

\section{References}

1. Modern environmental technologies in the electric power industry: information collection. Ed. V. Ya. Putilova (Moscow, Publishing house MPEI, 2007)

2. A.M. Kler, Mathematical modeling and optimization in the problems of operational control of thermal power plants (Novosibirsk, Science. SIF RAS, 1997)

3. Methodology for determination of gross and specific emissions of harmful substances into the atmosphere from boilers of thermal power plants. RD 34.02.30590 (Mocow, VTI, 1991)

4. Guidelines for the prevention of low-temperature corrosion of heating surfaces and boiler gas ducts. RD 34.26.105 (Moscow, VTI, 1995)

5. Methodology for calculating pollutant emissions from the combustion of coal-water fuel (Institute of Fossil Fuels NPO Gidrotruboprovod, 1990)

6. Thermal calculation of boilers (standard method) (SPb, NPO CKTI publishing, 1998)

7. M.V. Gritsenko M.V., A.M. Kler A.M., E.L. Stepanova E.L, Comprehensive methodology for determining costs when using different types of solid fuel at CHP. Scientific Bulletin of the Novosibirsk State Technical University. 4 (2008)

8. Guidelines for the calculation of pollutant emissions during fuel combustion in boilers with a capacity of up to $30 \mathrm{t} / \mathrm{h}$ (VTI, Moscow, Moscow branch of Hydrometeoizdata, 1985) 